AJIE - Asian Journal of Innovation and Entrepreneurship

(e-ISSN: 2477- 0574; p-ISSN: 2477-3824)

Vol. 02, No. 01, January 2017

\title{
MANAGERIAL AND BEHAVIOR EDUCATION AND TRAINING BUSINESS DEVELOPMENT THROUGH EXPERIENTIAL LEARNING METHOD
}

\author{
Andi Iswoyo $^{1}$, Didik Daryanto ${ }^{2}$, Wahtu Nugroho ${ }^{3}$ \\ 1 Accountancy, University Putra Wijaya, Surabaya, Indonesia \\ 2 Agribusiness, University Putra Wijaya, Surabaya, Indonesia \\ 3 Mechanical Engineering, University Putra Wijaya, Surabaya, Indonesia \\ *Corresponding E-mail : andi@uwp.ac.id
}

\begin{abstract}
Education and training effort Managerial Behavior developed using experiencebased education methods (Experiential Learning), which is the process of learning in which learners combining knowledge, skills and values through direct experiences through outdoor activities. Business development goals are to meet the needs of the communitybased education and training of the EL. The method of implementation is applied is to maintain the existing condition of raw materials / clients, improve services through the ownership of assets, equipment, understand the needs of clients and supervision, good management, marketing strategy of segmenting and targeting, pricing, promotion, and human resources are adequate. Our operating results have been achieved which is kept to maintain the existence of raw materials / clients, improvement of service procedures, improvement of security procedures, create training modules, the addition of new games, website development company and information management systems training, adjustment of the price of services, developing services such as construction outbound park and camping ground, include employees and facilitators in the training of tax and e-SPT, workshop Facilitating Skill for Rope Courses, workshop First Aid and High Ropes, Certified facilitator and workshops in the other, to develop cooperation with the Asosiasi Experiential Learning Indonesia (AELI) and Himpunan Provider Outbound Indonesia (HPOI), as well as establish business entities Limited Company and register the business brand. The impact was an increase in revenue from year to year.
\end{abstract}

Keywords: Business, Education, Training, Experiential Learning

\begin{abstract}
ABSTRAK
Pendidikan dan usaha pelatihan Perilaku Manajerial dikembangkan menggunakan metode pendidikan berbasis pengalaman (Experiential Learning), yang merupakan proses pembelajaran di mana peserta didik menggabungkan pengetahuan, keterampilan dan nilai-nilai melalui pengalaman langsung melalui kegiatan di luar ruangan. tujuan pengembangan usaha yang memenuhi kebutuhan pendidikan dan pelatihan dari EL berbasis masyarakat. Metode pelaksanaan yang diterapkan adalah untuk menjaga kondisi yang ada bahan baku / klien, meningkatkan layanan melalui kepemilikan aset, peralatan, memahami kebutuhan klien dan pengawasan, manajemen yang baik, strategi pemasaran segmentasi dan targeting, harga, promosi, dan sumber daya manusia yang memadai. Hasil
\end{abstract}




\begin{abstract}
operasi kami telah dicapai yang disimpan untuk mempertahankan keberadaan bahan baku I klien, perbaikan prosedur pelayanan, perbaikan prosedur keamanan, membuat modul pelatihan, penambahan game baru, perusahaan pengembangan situs web dan pelatihan sistem informasi manajemen, penyesuaian harga jasa, mengembangkan layanan seperti taman konstruksi outbound dan camping ground, termasuk karyawan dan fasilitator dalam pelatihan pajak dan e-SPT, lokakarya Memfasilitasi Keterampilan untuk Program Rope, lokakarya Pertolongan Pertama dan High Ropes, fasilitator bersertifikat dan lokakarya di lainnya, untuk mengembangkan kerjasama dengan Asosiasi Experiential Learning Indonesia (AELI) dan Himpunan Provider Outbound Indonesia (HPOI), serta membangun badan usaha Perseroan Terbatas dan mendaftarkan merek bisnis. Dampaknya adalah peningkatan pendapatan dari tahun ke tahun.
\end{abstract}

Kata kunci: Bisnis, Pendidikan, Pelatihan, Experiential Learning

\subsection{Introduction}

The business unit IbKIK (Science and technology for Creativity and Innovation Campus) developed by the so-called IbKIK Services Managerial Behavior Education and Training Universitas Wijaya Putra (IbKIK SMBET-UWP) with main activities as a provider of education and behavioral training primarily conduct in the management process in the organization that conducted outside space (Outdoor Training). This type of business targeted by UWP because UWP has a highly qualified resources in various fields of knowledge management and human resources, other than that no provider of outdoor education and training that focuses on the education and training of managerial behavior.

UWP also has a laboratory management and behavioral studies with sufficient facilities, established to create a dynamic synergy between the UWP expertise's possessed by the human resource development of what will be an important part of people's needs. There is now a kind of training providers, however IbKIK SMBET-UWP unique/ advantages compared to other similar training services that have been circulating in the community.
Uniqueness / advantages include: Content Focus on education and training of behavior and every one semester once held update training materials, training methods consist of Class, Games, Discuss and questioners, business from professional agencies, facilitators who have the basic education that qualified and EL experienced, selfowned facilities were adequate and qualified support personnel.

\subsection{Products and Product Specifications}

Education and training efforts in IbKIK SMBET-UWP is a business that is designed to:

1. Provide for the participants understanding of the behavior of individuals, between individuals and groups and their influence on the work process within the scope of each organization.

2. Approaching the reality of the problems in the organization, so the approach taken in this training is an interpretive approach / constructivism. Trainees are invited to understand the material in a way to interpret the existing reality.

3. Understand the supporting factors and obstacles along the interaction is then 
implemented in the world of organization/ workplace.

\subsection{Methods and Materials}

The training is done by several methods: Class, Game, Discuss and Questionnaire. The training materials were given to adjust to the needs of clients (tailor made), some of the materials that can be delivered include: Sociological Paradigm; Communication; Personality; Interpersonal Relations; Motivation; Team Work and Organizational Change.

At the end of training evaluation and analysis of results are communicated back to the customer. Process cycle like this is done in full and repeated for all types of training to be undertaken by IbKIK SMBET-UWP.

\subsection{Facilities and Equipment}

Activities in the training conducted at the campus of the Universitas Wijaya Putra Training in Dsn. Barsari No. 24 Desa Gambiran Prigen Pasuruan. The campus has an area of $+3 \mathrm{Ha}$ equipped with adequate means outdoor activities, among others; Bedroom, bungalows, bathrooms, swimming pool, dining room, Fields of grass, Fields paving block, Joglo, Gazebo, space administration, facilitator room and storage, Mosque, Paintball Gun, LCD Projector, Sound System, Computer, Karaoke, Equipment game, among others: High rope (Flying Fox tower, Repelling, Two Line Bridge, etc.), Helm, Webbing, Harness, etc., Games, Hardware Documentation (DSLR cameras, etc.)

\subsection{Training process}

Stages of the training process as follows:
1. Promotional products, socialization and introducing training services to clients

2. Understand the needs of clients through gap analysis, Root Cause Analysis and find solutions

3. Preparing training materials, curriculum, presenters and facilities / accommodation required

4. Prepare the schedule, deliver material to the facilitator; pilot training if needed

5. The training begins with the delivery of content by the Team Leader; The division in small groups (8-12 trainee); The facilitator explains the rules of the game, followed participants completed the game; accompany and guide the participants to the discussion; fill out questionnaires, hope if there are things that are not expressed in the discussion, participants can put it in the questionnaire; plenary discussion; fill out questionnaires after training as a feedback on the training results

6. Create a report and evaluation of training; handed to clients along with a certificate

7. Examine the impact of training, improving the quality and supervision of the scheduled post-training

IbKIK impacts and benefits of social and economic aspects for the needs of the national community. Event Services IbKIK SMBET-UWP to further increase the effectiveness of cooperation with external partners, especially the industry and the public so that the external network can be built up well. Services activity results IbKIK SMBET-UWP directed aside in order to streamline the applied research activities as well as to raise funds that can be utilized for sustainability research. The public can get the proper training targeted 
and useful for the needs and development organization, other than that expected by the IbKIK SMBET-UWP these actors in this community can apply the knowledge gained from IbKIK SMBET-UWP this by making behavioral factors as a tool the new analysis in the management of human resources. Expediency derived from activities IbKIK SMBET-UWP services include:

1. Speeding up the process of developing a culture of entrepreneurship in UWP

2. Educate and nurture new entrepreneurial candidates for faculty and students prospective graduates UWP

3. Establish independent source of income for institutions and lecturers in UWP

4. Build a network of local government partners and industry

5. Assist the government in terms of creating job opportunities for university graduates

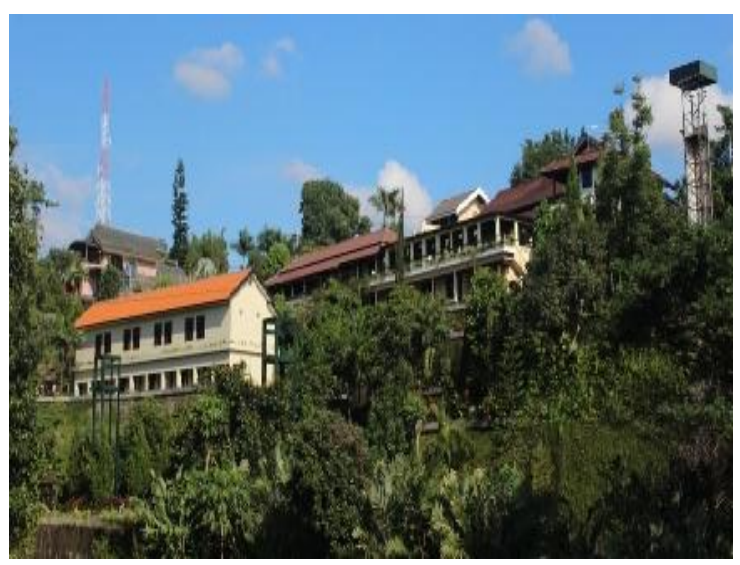

Figure 1 : Training Campus

\subsection{Method of Implementation}

Referring to the Situation Analysis item, following the business plan outlined aspects of the business by dividing activities into the following components:

\subsection{Raw material}

IbKIK SMBET-UWP Services is focused on education and training in behavior management processes within the organization with methods of education and training outside (outdoor training), which is the main raw material is the client who participated in this training from various sectors. IbKIK SMBET-UWP had stood since 2002, clients who have ever dealt with, among others, came from government agencies, educational institutions, state enterprises, private companies and from various levels ranging from middle managers, supervisors, principals, teachers, staff, students, students and etc.

With the experience of the above, of course, the existing condition of the raw material / client will remain good, we maintain good relationships with customers / clients through post-training evaluation and feedback as well as supervise the periodic post-training. We also always do the promotion and introduction into the recesses of the new market.

\subsection{Production}

In conducting its business, IbKIK SMBETUWP Services already has assets in the form of training equipment. Assets in the form of equipment owned by the current and future needs presented in, among others; Hardware ropes (high rope), metal equipment (high rope), security equipment, medical equipment, camp equipment, documentation equipment, electronic equipment, Paintball, equipment Games and other equipment. With total investment needed is Rp. 150,000,000 -

As a service business, it was realized that one of the vital role the process of service to the client, for it other than the design of the training, we will prepare standard operating procedures Training, SOP 
Security, Books Games Outdoor, Client Satisfaction Index (CSI), Books of Organizational Behavior, Outcomes Assessment Training and Managerial Behavior books. Hopefully, by the standard operating procedures and the books, we can deliver more value in terms of service to customers and reduce the gap between expectation / training objectives expected by the customer with the results of the training.

Systems are selected and applied to develop the business as follows:

1. Business Planning, Implementation of the results of university research include the study of the behavior, human resource development, organizational change, organizational culture, conflict management, risk management, and others;

2. Planning Product Marketing, maximize the use of media including leaflets, posters, brochures, banners, and electronic media such as the internet. Exclusively for the Internet, the promotion is done by promoting via web / social network. Maximizing return marketing strategies through word of mouth and marketing to optimize their special units that work to find new market niches.

3. Proposal of Credit, Cooperation and the recommendations of the UWP to get soft loans from the Bank;

4. The application of science and technology Selected Application of the results of the latest research related to human resources and organization, ecommerce application of technology;

5. Organizing Management, through the arrangement and will be implemented computerization of administration is by using management software administration;

6. Product Development and Production Process, through constantly improving the design of the training according to the needs of clients and the development of science, the development of human resource capacity, upgrading the knowledge and ability of the facilitator through further studies, and others.

Each participant who has attended training in IbKIK SMBET-UWP will receive a certificate signed by the Director. The certificate also contains the entirety of the material presented in the training. To be passed, and obtain the certificate, participants must meet several criteria set out in the regulations and standard operating procedures training.

P3M center-UWP has had a variety of facilities used to support the education and training process. Occupying an area of approximately 3 hectares, of which approximately 1 hectare used for building, approximately 1 hectare for a vehicle of outdoor activities and the rest is still used for a mini forest, which later was planned as a means of training activities.

\subsection{Training process}

IbKIK SMBET-UWP Services are services of education and training where the spear is excellent service (excellent service). The flow of business should be integrated with the quality control process as follows:

1. Marketing Promotional Products, socialization and introducing training services to clients. 
2. Assess, understand the needs of clients through gap analysis, Root Cause Analysis and find solutions

3. Design, prepare training materials, curricula, speakers and accommodation required

4. Prepare the schedule, deliver material to the facilitator;

5. Deliver, The training begins with the delivery of content; The division in small groups (8-12 people); implementation of the training; discussion; questionnaires; plenary discussion; fill out questionnaires after training as a feedback

6. Customer Services, reporting and evaluation of training; handed to clients along with a certificate.

7. Result, knowing the impact of training, improving the quality and supervision of the scheduled post-training

The training method used (Prasetyo, 2005), namely:

1. Class; This method is the initial method to deliver material to provide an initial conceptual framework as a starting point for subsequent studies.

2. Game; participants are invited to run an activity either on a group or individual in the form of a game. Game method selected for the game participants feel the direct interaction between individuals, between individuals and organizations, can feel directly what the limiting factor and drive the success of the team.

3. Discuss; Here the participants have the opportunity to express what they see, feel and do when the completion of tasks in progress in one group and plenary (between groups).
4. Questioner; this method as a means for participants to share what he understood in written form. In addition it can be used to record the participants' understanding, this method is also very useful for the participants who have psychological barriers to verbal expression.

Quality assurance system applied in IbKIK SMBET-UWP among others through; material adapted to the development of science and the needs of clients, as well as agreed upon at the beginning of training, the questionnaire after training as a feedback to the training, supervision, periodic post-training, Implementation standard operating procedures strict security and safety and health insurance through insurance. In the future we plan to use standard measuring training results in accordance with the development of existing science.

\subsection{Management}

At present there is still no production planning / services are applied in IbKIK SMBET-UWP. Production planning is only done when there are clients who request education and training services. Future is expected no target number of clients each month so that production planning can be done.

Bookkeeping is already done but have not been good, there are not in accordance with the rules akuntansy, need to increase

Never do auditing, but only from the internal auditor, while outside auditors (independent) of the public accounting firm has not been done. Sales tax liabilities have been paid in accordance with applicable regulations. Next needed a better 
understanding of the financial section on taxation through training.

The organizational structure where IbKIK SMBET-UWP directly under the Rector. IbKIK will stand alone unit parallel to the Technical Management Unit / Laboratory that already exists at the Universitas Wijaya Putra. IbKIK Unit at the Universitas Wijaya Putra there are currently four units: Unit IbKIK Appropriate Technology Machine and Tool Viewer, IbKIK SMBET-UWP, IbKIK Salted Eggs Low Cholesterol, IbIKK Services Education and training English language, IbKIK Talent Management Consultancy Services and IbKIK Virtual Legal Consultation. Unit IbKIK SMBET-UWP led by a Head of responsible directly to the Rector and the responsibility to initiate the operations unit IbKIK SMBET-UWP, directing manager of the unit IbKIK accordance with the duties and responsibilities of each and monitor the effectiveness and efficiency used fund services unit IbKIK SMBETUWP, whereas all financial activity, is centered in the financial Bureau Campus II Universitas Wijaya Putra.

The employees in this venture is composed of 32 people, divided into multiple tasks, among others; Head of Unit, Administration and Representative, Marketing, Technical and Business Development Division, Division of Human Resources Development and the Division of Research and Planning, facilitator, Room Boy and kitchen.

There is no inventory models used in the business-UWP IbKIK SMBET-UWP Services, as business services, supply of raw materials in this case the client is highly dependent on orders from clients and marketing efforts undertaken. The future will be enforced model of supply of raw materials, using the average inventory system, where every month on a regular basis in quantity there is an order from a client.

\subsection{Marketing}

Currently IbKIK SMBET-UWP has had a clear market positioning. Based on data from clients who have joined P3M-UWP, the potential market is government agencies, educational institutions, state enterprises, private companies and from various levels ranging from middle managers, supervisors, principals, teachers, staff, students, students and others in East Java. Our efforts to expand the market will do in the Outer Eastern colleagues by disseminating information to the sales force and clients (word of mouth)

This method maximizes the use of media including leaflets, posters, brochures, banners, and electronic media such as the internet. Exclusively for the Internet, the promotion is done by promoting via web / social networks as a source of information and material. Marketing strategies that most perceived benefits is through word of mouth. Prices are set based on the cost of accommodation (meals, t-shirts, snacks, etc.), the cost of lodging, equipment, facilitators, certificates, insurance, etc. Level of consumer marketing target is the manager of the company / institution, supervisors, employees, teachers, students and the students. As for the target market of government agencies, educational institutions, state enterprises, private companies and from various levels ranging from middle managers, supervisors, principals, teachers, staff, students, students and others. Development can be carried out on a new market niche is to work with businesses / agencies both government and private sectors for the development of human resources as a whole through an 
employment contract, as well as the diversification of products.

IbKIK SMBET-UWP-sharing cooperation with institutions that have affiliations with UWP to mutually promote and reinforce each other so that the position can be obtained progress together. Cooperation is also carried out at government agencies and private institutions that become market segments IbKIK SMBET-UWP. In addition we establish a relationship with the client through the scheduled post-training supervision, it is to get closer to clients and determine the impact of training for clients as well as knowing the client's needs further.

\subsection{Human Resources}

In terms of employee education, is sufficient qualification S3, S2 and S1 and are in accordance with the needs. But it remains necessary developments of human resources through training and workshops, among others that can be given, namely: leadership development, training Psychology employee, Training Behavior Managerial, administrative offices, application of computer, Accounting and Taxation, Implementation of financial software, marketing techniques and negotiation, e -commerce and networking, psychology and behavior of employees, standardization of the facilitator through the certification of facilitators, development of managerial knowledge, outdoor education TOT, Excellence services, Mountaineering high rope, first aid in an emergency, etc.

\subsection{Financial}

Cash flow herein is intended to describe how IbKIK SMBET-UWP manage the smooth running of cash in the business, so they can be healthy and whether the liquidity of this business. In 2015, the business unit posted net profit increased significantly compared to the previous year by $10.5 \%$.

Internal Rate of Return (IRR) is intended to provide an overview of business feasibility (Muchtar, 2010), by comparing the IRR presentation to the magnitude in terms of the interest rate Bank loans current. The results of calculation of IRR known that the IRR is between $15 \%$ and $20 \%$, amounting $=17.62 \% /$ year or rounded $=18 \%$. Conclusions from the calculation of the Internal Rate of Return (IRR) of the above can be interpreted that the business IbKIK SMBET-UWP Services can be categorized as very interesting to do, because discount applicable Bank to obtain credit from the Bank can be obtained with the loan interest below $15 \%$.

\subsection{Conclussion}

In the implementation of the program IbKIK SMBET-UWP third year, many developments are earned by managers of business units, income generation, capacity building of human resources, an increase in the extent of the market, an increase in assets and facilities, and others. Here is presented the achievement of the third anniversary of the grant IbKIK SMBETUWP, as follows:

\subsection{Raw Materials}

The development of the target market, has scheduled regularly at least once every 2 months for open targets and new market segments, marketing undertaken include hearings in SMP Dorowati Surabaya, SMP Negeri 5 Surabaya, SMP Negeri 14 Surabaya, SMP Negeri 45 Surabaya, SMP Negeri 52 Surabaya, PT. Pegadaian (Persero), Bappeda Jombang, RSUD Bojonegoro, RSUD Madiun, RSUD Pasuruan, RSUD Jember and others. 
The development of new market segments, still schedulled routine, planned after the existing website is updated, it will be scheduled for the development of new market segments three times a month.

\subsection{Production}

SOP training, be improved in some procedures, especially if there is a change in the type of business / culture of the client company received. SOP Security, conducted continuously, especially after receiving input from the training High Rope, many procedures are improved. Compilation Books Outdoor Games, Books draft has been prepared and is currently signed to the printer for immediate printing and get an ISBN. Completion books Outdoor Games and publishing a book for ISBN. Preparation of the Client Satisfaction Index (CSI), the index has been created in the first year followed to determine the level of client satisfaction. There are multiple revisions of related sentences that questions need to be refined. Today still use ServQual (Parasuraman, 1985) as a method. The need for supervision of the improvement efforts of the analytical results of this CSI.

Preparation of Organizational Behavior Books, is now published by the Organizational Behavior Books ISBN 978602-9310-62-7 compiled by Suprayoga, SE., M.Sc. and Andi Iswoyo, SE., MM. The uniqueness of this book is on unit activities, in addition to featuring a matter to determine the level of student understanding, this book also comes with a case study and activity games, which strengthen students' understanding of the particular concept. Preparation Training Outcomes Assessment of existing formats of training outcomes assessment, but continued effort repair and Preparation
Books Managerial Behavior in which the existing draft is still continuing refinement, is associated with the development of the business world and the concept continues to grow.

\subsection{Process}

In the process of the service, already adding 16 new games, a concept which is built in each of the games is well defined through Training Information System that we developed, but the deepening of the material any games still need to be strengthened and the designation for a social level consumers also need to be enhanced. The increase in the number of game this was offset by an increase in delivery methods to be more varied through the facilitation of technical training and new training methods, including through training Neuro Lingustic Programming (NLP) for Outbound Training, hypnosis and Hypnotherapy.

Outbound Park / Rope Course was developed in the first year, this year to do maintenance on some parts, such as a rope, board buffer, lubrication steel wire, tree condition, the painting and the next stage will be held overhaul of track circuits follow the contours and level of difficulty of the circuit,

Paintball Battle Field development is currently still using the field, but enhanced by enriching with obstacles made of pallets, drums, crates, flags and others. The development is also done on the rejuvenation of the tools, the procurement goggle / helmets, armor and more.

Camping Ground which was built in the second year with a capacity of 17 tents (68 people), equipped with tents, mattresses, sleeping bags and cooking equipment, today Camping Ground has been equipped with lights, electricity, water supply, arena 
campfire, trekking exploration and more. Currently it has no capacity expansion and refinement of the concept Camp and effort to Flying Camp.

Farm Field Development is currently preparing the construction, including setting up and clearing the land, prepare the beds for seedlings and diversifying crops land through matching funds from the University. It is still hampered by permission of the Foundation in the allotment of land is still empty.

Quality Assurance System, there have been continuing efforts to improve, in relation to the assessment tool and audit. There is already a data base on the results of research and browsing the Internet related to the development of science especially managerial behavior. One example is the development of the concept of leadership to the concept of Result Based Leadership (Dave Ulrich), utilization theory Neuro Linguistic Programming (NLP) for Outbound Training, Hypnosis and Hypnotherapy, and others.

\subsection{Management}

Existing production targets during the first year, in the first year, the target of the service until the month of July 2016 has reached $45 \%$ and the expected increase in revenues of $12 \%$ at the end of the year from the previous year, it can be seen from the service order received, including from Kabupaten Rengat, Kabupaten Balik Papan, Kabupaten Parigi Moutong, RSUD Bojonegoro and others.

Trial balance and financial statements neat. Already using financial software but still need to be optimized consumer. Cycle diaries, ledgers, trial balance and financial statements neat. This year the internal audit had not been realized, planned for the end of 2016. The financial examination is conducted with the budget and realization. In the event that the tax has been remitted and reported in accordance with improvements pattern based management and management functions include planning, organizing, actuating and controlling. The model of supply of raw materials, products using the average inventory system.

\subsection{Marketing}

Dissemination, publication and promotion unit in the internal and external IbKIK been scheduled every month. Among them is done by re-visiting clients who have not joined us as well as cooperating teachers who conduct research in several agencies at the same time defining the product-UWP SMBET services.

Already there are clear rules of the meeting in the first year and to date continues to do. The preparation of the database needs of clients, conducted in cooperation with the Association of Experiential Learning Indonesia (AELI) and the Association of Indonesian Outbound Provider (HPOI) to determine the business market EL / Outbound in Indonesia and storage of data via the Management Information System Web-based training.

Search of new market niches has scheduled one month while maintaining marketing with brochures, leaflets and spread of the proposal / company profile. Another effort is still in the development of websites and web-based information system training for the company. Enhance Information System Web-based training to develop and improve services and marketing

Selling price of products is also constantly adjusted by taking into account the needs and capabilities of the market, especially to clients with limited financial resources, such as schools, charities, NGOs, the 
selling price is distinguished by large companies. It is also a form of CSR through cross-subsidies.

\subsection{Human Resources}

Several attempts to improve the ability of the proposer and the Task Force Facilitator of which include the Workshop Facilitation Skills for Rope Course held on 19-21 February 2016 in Prigen UWP Campus in collaboration with the Association of Experiential Learning Indonesia (AELI) Pengda East Java, this training provides skills development facilitating the access program leash / rope access often used in outdoor training. Speakers in the workshop was Tony Dumalang, Experiential Learning Facilitator of Jakarta. The workshop was attended by the facilitator of The Bridge Outdoor Education and facilitator of outbound provider in East Java, some 65 people.
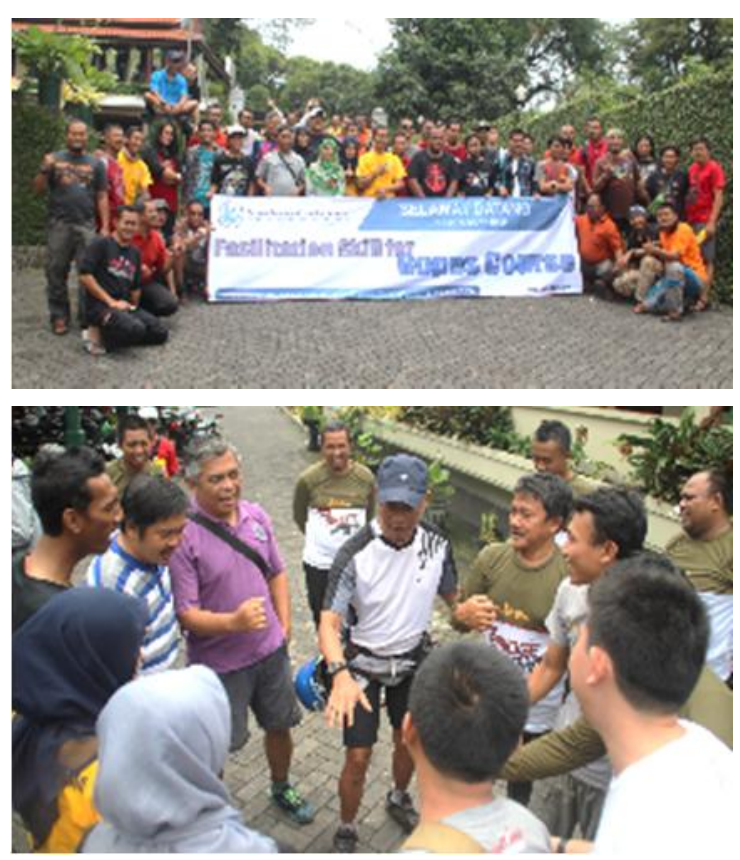

Figure 1 : Workshop Facilitation Skills for Rope Course

The training was also conducted in order to develop the ability Facilitator is to include three people in Basic Training and Advanced Hypnosis and Hypnotherapy organized by the Indonesian Board of Hypnotherapies (IBH) and three nonacademic graduate earned a Certified Hypnotist (CH.) And Certified Hypnotherapist (C.Ht). This training aims to enrich and develop scientific training methods in training outside of space-based Experiential Learning.

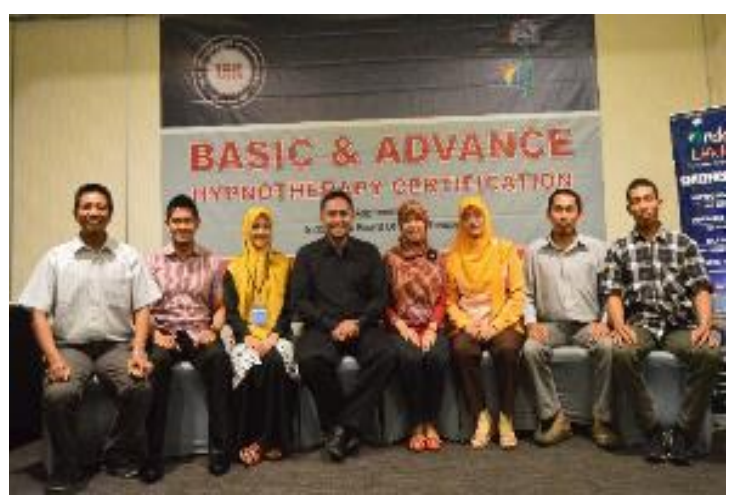

Figure 8 : Basic Training and Advanced

Hypnosis and Hypnotherapy

It is also always active in meetings, workshops or orientation organized by AELI Regional Board East Java and Indonesia Outbound Provider Association, including Member Orientation Workshop and AELI in Madiun and Gathering HPOI in Wonosalam, Batu and Surabaya.

As for the other training that will be followed, among others Workshop NLP for Outbound Training Academy (NOTA) organized by the Association of Indonesian Outbound Provider (HPOI) and NLP for Practitioner (certified) as well as for the employees to be included in the workshop excellent service.

\subsection{Facilities}

Things that until now has not been realized is building new rooms, it is associated with funding and policy foundations, but already there is increasing room facilities, including the replacement of some beds, sheets, 
pillows, a fan, a bathroom improvement, procurement of bathroom fixtures, etc. , Bathroom additions are also yet to be realized because they adapt to the needs that are still in short supply, but has made improvements and improved bathroom facilities.

Joglo is currently able to accommodate 75 people, there has been no increase in capacity caused by the results of discussions with the Foundation, yet needed because there has not been a client of more than 75 people. In July 2016 joglo ceiling renovations have been done, this is to avoid leaks when it rains and beautify the look joglo.

Checking, repair and rejuvenation equipment continue to be made. Activity tool checks carried out at any time before and after using the tool by facilitators who use these tools.

\subsection{Financial}

The use of financial software for business operations already carried out and in need of optimization as well as updated software and personnel carriers.

Until July 2016, the third year revenue target has been achieved $45 \%$ is expected to end this year there could be an increase of $12 \%$ from last year.

\subsection{Other}

In the framework of Good Corporate Governance, are now formed the company legal form of a Limited Liability Company (PT), PT. Dua Jumar. PT is a development line of business in the PT that has been owned by the Foundation. This was done to simplify and accelerate the creation of service PT.

\subsection{References}

[1]Prasetyo, Indra, 2005, Perilaku Manajerial, The Bridge Outdoor Education, Surabaya

[2]Muchtar, AF., 2010, Panduan Praktis Stategi Memenangkan Persaingan Usaha dengan Menyusun Business Plan, Elex Media Komputindo, Jakarta 